\title{
JOURNAL.RU
}

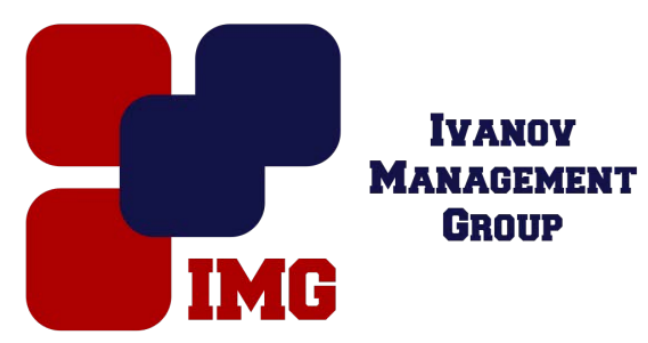

\author{
Кузнецова Ю.Л. \\ Финуниверситет при Правительстве РФ \\ Москва, Россия
}

doi: 10.18411/lj-28-02-2017-2-02

idsp 000001:lj-28-02-2017-2-02

\section{Таможенное и налоговое право ЕАЭС: теоретико-правовые аспекты развития на современном этапе}

\section{Аннотация}

Статья посвящена выявлению проблем развития таможенного и налогового законодательства в рамках Евразийского экономического союз. В рамках данной статьи автором рассмотрены теоретико-правовые аспекты, влияющие на развитие налогового и таможенного права.

Ключевые слова: Евразийский экономический союз, таможенное право ЕАЭС, налоговое право ЕАЭС, Таможенный кодекс ЕАЭС, развитие ЕАЭС.

На современном этапе развития международные союзы набирают все большую популярность. Евразийский экономический союз, который на данный момент объединил 5 государств, является ярчайшим примером развития экономических отношений в современном мире. Часть исследователей процесс евразийской экономической интеграции рассматривают этот феномен как в целом идеологический и политический проект с минимумом экономического обоснования. ЕАЭС видится именно как заложник амбиций правящих политических элит части постсоветских государств при отсутствии единого понимания главных общих интересов [2]. С другой стороны, сами участники заявляют об исключительно экономическом союзе. В ст.1 договора о ЕАЭС устанавливается, что его стороны учреждают Евразийский экономический союз, в рамках которого обеспечивается свобода движения товаров, услуг, капитала и рабочей силы, проведение скоординированной, согласованной или единой политики в отраслях экономики, которые определяются данным договором и международными договорами в рамках Союза. В договоре об учреждении ЕАЭС уточняется, что государства-члены принимают на себя обязательства осуществлять согласованную политику в ключевых отраслях своей экономики, таких как энергетика, промышленность, сельское хозяйство, транспорт [5].

На данный момент в Евразийский экономический союз входит пять государств: Россия, Белоруссия, Казахстан с 1 января 2015 года, Армения со 2 января 2015 года и Киргизия с 12 августа 2015 года. Безусловно, со стороны 
бизнеса, прежде всего встает вопрос об усовершенствовании таможенного и налогового законодательства ЕАЭС, так как у пяти стран собственные таможенные и налоговые правила, которые требуют унификации.

Начнем с анализа состояния таможенного права на данный момент. Хорошо известно, что сейчас в разработке находится проект таможенного кодекса ЕАЭС, который, по мнению специалистов, должен вступить в силу с 2017 года. Данный кодекс должен прийти на смену ТК ТС и учитывать интересы всех пяти странучастниц.

До вступления в силу Таможенного кодекса ЕАЭС таможенное регулирование в международной организации осуществляется в соответствии с Таможенным кодексом Таможенного союза (ТК ТС) (Принят Решением Межгосударственного Совета ЕврАзЭС на уровне глав государств от 27.11.2009 N 17) и иными международными договорами государств-членов, регулирующими таможенные правоотношения, заключенными в рамках формирования договорноправовой базы ТС и Единого экономического пространства и входящими в соответствии со ст. 99 Договора в право ЕАЭС. Ниже приведем перечень документов, продолжающих действовать после вступления в силу Договора.

1. Соглашения между Правительством РФ, Правительством Республики Беларусь и Правительством Республики Казахстан:

- "Об определении таможенной стоимости товаров, перемещаемых через таможенную границу Таможенного союза" (от 25.01.2008);

- "О некоторых вопросах предоставления обеспечения уплаты таможенных пошлин, налогов в отношении товаров, перевозимых в соответствии с таможенной процедурой таможенного транзита, особенностях взыскания таможенных пошлин, налогов и порядке перечисления взысканных сумм в отношении таких товаров" (от 21.05.2010);

- "О свободных складах и таможенной процедуре свободного склада" (от 18.06.2010);

- "О порядке перемещения физическими лицами товаров для личного пользования через таможенную границу Таможенного союза и совершения таможенных операций, связанных с их выпуском" (от 18.06.2010).

2. Соглашение об основаниях, условиях и порядке изменения сроков уплаты таможенных пошлин (заключено в г. Санкт-Петербурге 21.05.2010).

3. Соглашение об особенностях таможенного транзита товаров, перемещаемых железнодорожным транспортом по таможенной территории Таможенного союза (заключено в г. Санкт-Петербурге 21.05.2010).

4. Соглашение о представлении и об обмене предварительной информацией о товарах и транспортных средствах, перемещаемых через таможенную границу Таможенного союза (заключено в г. Санкт-Петербурге 21.05.2010).

5. Соглашение о Едином таможенном реестре объектов интеллектуальной собственности государств - членов Таможенного союза (заключено в г. СанктПетербурге 21.05.2010).

6. Соглашение об особенностях таможенных операций в отношении товаров, пересылаемых в международных почтовых отправлениях (заключено в г. Санкт-Петербурге 18.06.2010).

7. Соглашение об освобождении от применения таможенными органами 
государств - членов Таможенного союза определенных форм таможенного контроля (заключено в г. Санкт-Петербурге 18.06.2010).

8. Соглашение по вопросам свободных (специальных, особых) экономических зон на таможенной территории Таможенного союза и таможенной процедуры свободной таможенной зоны (заключено в г. Санкт-Петербурге 18.06.2010).

9. Соглашение об особенностях использования транспортных средств международной перевозки, осуществляющих перевозку пассажиров, а также прицепов, полуприцепов, контейнеров и железнодорожного подвижного состава, осуществляющих перевозку грузов и (или) багажа для внутренней перевозки по таможенной территории Таможенного союза (заключено в г. Санкт-Петербурге 18.06.2010).

10. Договор о порядке перемещения физическими лицами наличных денежных средств и (или) денежных инструментов через таможенную границу Таможенного союза (подписан в г. Астане 05.07.2010).

Помимо указанных основных международных договоров действует ряд иных соглашений, которые в менышей части касаются субъектов хозяйствования.

По мнению экспертов, ТК ТС устарел, так как опирается на нормы, которые «транслировались из кодекса в кодекс, начиная с 1990-х годов, когда внешнеэкономическая деятельность (ВЭД) кардинальным образом отличалась от той, которую ведут хозяйствующие субъекты сейчас» [4]. Таким образом, необходим новый кодекс, который будет учитывать как мнение бизнеса, так и интересы государств.Необходимо отметить, предприниматели желают, чтобы таможенное регулирование было прозрачным, понятным и необременительным. В проекте кодекса должно устраняться избыточное регулирование, сокращаться сроки совершения таможенных операций благодаря повсеместному использованию информационных технологий, создаваться условия для эффективного использования ресурсов таможенных органов.

Информатизация таможенной системы - вот ещё одна проблема, крайне актуальная на современном этапе, так как не все таможенные пункты имеют реальную возможность ввести электронное декларирование из-за нехватки материальной базы. Иными словами, заявленная разработчиками ТК ЕАЭС информатизация на данном этапе не является возможной и реально выполнимой, что может быть еще одной причиной задержки введения нового кодекса в силу.

Также большую проблему составляет различия в законодательстве, которое регулирует особенности перемещения транспортных средств международной перевозки. Особенно проблемным является запрет на использование временно ввезенных автомобилей для совершения внутренних перевозок по территориям государств ТС, который противоречит транспортному законодательству странучастниц. Также, касаемо железнодорожного транспорта, есть затруднения с возможностью передавать вагоны, которые используются для международных перевозок, получателям товаров в том случае, если эти вагоны являются собственностью самих получателей, а не железной дороги [4]. Эти проблемы должны быть решены в новом Таможенном кодексе ЕАЭС.

Еще одним немаловажным аспектом развития права Евразийского экономического союза является развитие налогового законодательства. Эксперты предлагают взять за основу налоговое право $\mathrm{EC}$, так как цели функционирования у ЕС и ЕАЭС схожи: экономическое развитие стран-членов и создание свободного 
от барьеров рынка внутри союзов. Конечно, есть различия в структуре органов и их функционировании, но сама основная идея остается неизменна. Налоговое право ЕС представляет собой совокупность налоговых положений учредительных договоров и нормативного-правовых актов, принятых институтами ЕС, общих принципов европейского права, применяемых к налоговым отношениям, и решений Суда ЕС по налоговым вопросам. На данном этапе развития в ЕАЭС нет никакого единого налогового законодательства.

Возможность действия комиссии ограничена рядом сфер напрямую в которые не входит налоговое право, но есть указания на иные сферы, определенные договором т. е. перечень является открытым. Согласно п. 3 ст. 73: «Государства-члены определяют направления, а также формы и порядок осуществления гармонизации законодательства в отношении налогов, которые оказывают влияние на взаимную торговлю, чтобы не нарушить условия конкуренции и не препятствовать свободному перемещению товаров, работ и услуг на национальном уровне или на уровне Союза, включая: 1) гармонизацию (сближение) ставок акцизов по наиболее чувствительным подакцизным товарам; 2) дальнейшее совершенствование системы взимания налога на добавленную стоимость во взаимной торговле (в том числе с применением информационных технологий)[3]»

В Российской Федерации сформирована «федеральная» структура налогового законодательства, включающая три его уровня (федеральный, региональный и местный). В остальных унитарных государствах ЕАЭС образовалось «монолитное» налоговое законодательство, представляющее собой единый нормативный правовой массив, совокупность нормативных правовых актов, принимаемых в соответствии с налоговым кодексом для регулирования налоговых отношений.

Все иные акты налогового законодательства производны от налогового кодекса и не могут ему противоречить. Если в России налоговое законодательство формируется через объединение законодательных актов (федеральных и региональных законов о налогах и сборах, нормативных правовых актов о налогах и сборах, принятых представительными органами местного самоуправления), то в других государствах ЕАЭС налоговое законодательство включает в свойсостав как законодательные акты, так и иные источники налогового права международные договоры, подзаконные акты.

В налоговом кодексе может устанавливаться запрет на включение налоговых норм в непрофильные («неналоговые») законодательные акты. Такой запрет направлен на избежание коллизий между lexgeneralis и lexspecialis при регулировании налоговых отношений[6].

Таким образом, развитие унифицированных кодексов в рамках Евразийского экономического союза поможет оптимизировать процесс взимания таможенных пошлин и налогов. 


\section{Литература}

1. Федеральный закон «О таможенном регулировании в Российской Федерации» №311-Ф3 от 27.11.2010года

2. Вьюнов В. Н., Филиппова М. Г., Мамедов Р. М., Коротовский В. В., Рзаева Е. А., Кофанов В. А. Некоторые перспективы и противоречия развития ЕАЭС // Молодой ученый. — 2016. — №8. - С. 520-523.

3. Договор о Евразийском экономическом союзе от 29.05.2014 [Электронный pecypc] - // URL: http://eaeunion.org/ (Дата обращения 15.04.2016).

4. Интервью с Владимиром Гошиным - [Электронный ресурс] - // URL: https://rg.ru/2014/09/02/tamozh.html - дата обращения 15.12.16

5. Капустин А.Я. Право евразийского экономического союза: подходы к концептуальному осмыслению // Современный Юрист. - 2015. - №1(10) январь - март.

6. Козырин А.Н. Кодификация налогового законодательства в государствах Евразийского экономического союза // Реформы и право, 2015.- №4.-С.3441. 